\title{
COLD AGGLUTININS. IV. CRITICAL ANALYSIS OF CERTAIN ASPECTS OF THE METHOD FOR DETERMINING COLD ISOHEMAGGLUTININS
}

\author{
By MAXWELL FINLAND, BERNARDO A. SAMPER, AND MILDRED W. BARNES \\ WITH THE TECHNICAL ASSISTANCE OF MURIEL B. STONE \\ (From the Thorndike Memorial Laboratory, Second and Fourth Medical Services (Harvard), \\ Boston City Hospital, and the Department of Medicine, Harvard Medical School, Boston)
}

(Received for publication September 22, 1944)

The data recorded in the previous papers of this series are based upon tests carried out in a more or less uniform manner. The method of testing for cold agglutinins (1) is essentially the one which has been found (2) most suitable in the studies of blood from cases of hemolytic anemia. It was readily reproducible when the same materials were employed in repeated tests carried out at the same time. When, however, the same sera were retested on other occasions, slight, and sometimes considerable, differences in titer were noted. For that reason, as these investigations progressed, batches of sera were subjected to comparative tests, using the routine method and some variation of this method. The present paper is devoted to a critical evaluation of certain details of the quantitative technique for determining cold agglutinins in human serum as revealed by-these comparative tests. Most of the data were accumulated during the course of the present investigations, but some were the results of separate experiments.

EFFECT OF AGE OF CELLS ON COLD ISOAGGLUTININ TITERS

It was noted early in the course of these studies that some sera in which cold agglutinins could not be demonstrated with cells that were used on the day the blood was drawn nevertheless showed significant titers when tested with the same cells after they had been allowed to stand 3 or 4 days. It seemed important, therefore, to determine how often and to what extent this phenomenon occurred. A number of sera were, therefore, tested simultaneously with cells obtained on different days from the same donor.

Tests of cold agglutinins were usually carried out 2 or 3 times each week throughout this study. On a number of these occasions, batches of sera, both positive and nega- tive, were tested at the same time with fresh or 1-day-old cells and with other cells from the same donor that had been used for previous tests and were 3 or 4 days old at the time. The cells had remained suspended in saline during this period. They were kept in a refrigerator when not in use and were discarded if hemolysis occurred. A single set of dilutions was made and distributed in duplicate tubes in order to minimize errors from this source. In these tests and in the succeeding ones, all of the agglutinations were observed at $4^{\circ} \mathrm{C}$. and were completely reversed at $37^{\circ} \mathrm{C}$.

The accumulated results of the comparative tests are shown in Table I. One-fourth of the sera showed the same titers with the fresher and with the older cells, but almost twice as many showed higher titers with the older cells. When compared separately, lower titers were more frequent with fresh than with 1-day-old cells and higher titers were somewhat more frequent with 4-day-old cells than with 3-day-old cells. An appreciable number of sera which gave no agglutination in a dilution of $1: 10$ (the lowest dilution tested) when fresh or 1-day-old cells were used, yielded titers ranging from 10 to 320 with 3 - or 4-day-old cells. A similar number of positive sera showed titers which were 8 or more times greater with the older than with the fresher cells. These observations indicate that 3- or 4-day-old cells are appreciably more sensitive to agglutination in the cold than are fresh or 1-day-old cells except in sera having a high content of cold agglutinins.

\section{COMPARISON OF RESULTS WITH CELLS FROM DIFFERENT DONORS}

In the preceding comparisons, the cells used in the tests of each serum were obtained from the same donor. It was not feasible to use a single donor throughout all of the studies. It was of interest, therefore, to obtain information on the extent to which variations in the titer of cold ag- 
TABLE I

Comparison of cold isohemagglutinin titers (end-point + ) of the same sera tested simultaneously with fresh or 1-day-old cells and with 3 or 4-day-old cells of the same donor

\begin{tabular}{|c|c|c|c|c|c|c|c|c|c|c|c|c|}
\hline \multirow{2}{*}{$\begin{array}{c}\text { Titer with } \\
\text { fresh or } \\
\text { 1-day-old } \\
\text { cells }\end{array}$} & \multicolumn{11}{|c|}{ Titer with 3 or 4-day-old cells } & \multirow{2}{*}{ Total } \\
\hline & $<10$ & 10 & 20 & 40 & 80 & 160 & 320 & 640 & 1280 & 2560 & 5120 & \\
\hline $\begin{array}{r}<10 \\
10 \\
20 \\
40 \\
80 \\
160 \\
320 \\
640 \\
1280 \\
2560 \\
5120\end{array}$ & $\begin{array}{l}1 \\
3 \\
1\end{array}$ & 2 & $\begin{array}{l}5 \\
3 \\
2 \\
1 \\
1\end{array}$ & $\begin{array}{r}8 \\
4 \\
9 \\
11 \\
2 \\
4\end{array}$ & $\begin{array}{r}5 \\
2 \\
8 \\
13 \\
7 \\
6 \\
7\end{array}$ & $\begin{array}{r}2 \\
3 \\
10 \\
25 \\
24 \\
22 \\
15\end{array}$ & $\begin{array}{r}2 \\
1 \\
5 \\
7 \\
11 \\
33 \\
18 \\
5\end{array}$ & $\begin{array}{r}2 \\
2 \\
9 \\
26 \\
13 \\
5\end{array}$ & $\begin{array}{l}1 \\
1 \\
3 \\
1\end{array}$ & $\begin{array}{l}1 \\
4 \\
2 \\
1\end{array}$ & 1 & $\begin{array}{r}24 \\
9 \\
22 \\
49 \\
47 \\
55 \\
95 \\
49 \\
10 \\
1 \\
1\end{array}$ \\
\hline Total & 5 & 4 & 12 & 38 & 48 & 101 & 82 & 57 & 6 & 8 & 1 & 362 \\
\hline
\end{tabular}

SUMMARY

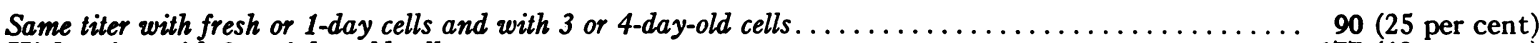

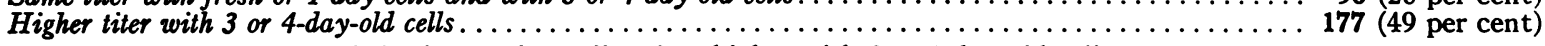
$<10$ with fresh or 1-day cells, 10 or higher with 3 or 4 -day-old cells . . . . . . 24

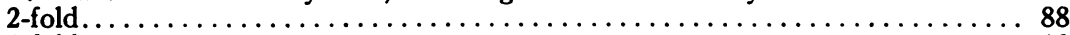

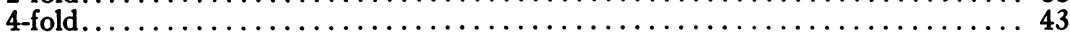

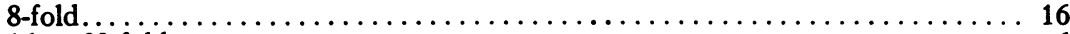

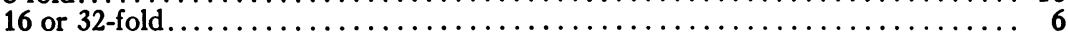

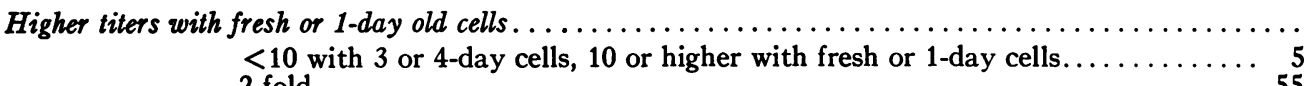

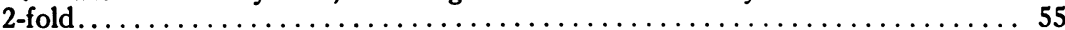

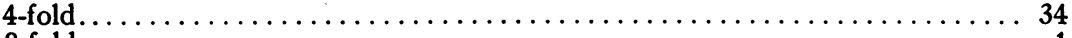

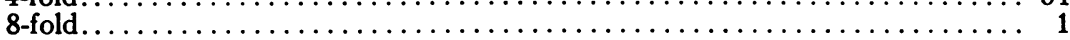

95 (26 per cent)

Note: The 95 sera in which the titer with fresh or 1-day cells was 320 were about equally divided among those having the same (35 per cent), higher ( 30 per cent), and lower ( 35 per cent) titers with the older cells.

Among the 206 sera in which the titer with the fresher cells was less than 320,69 per cent had higher titers with 3 or 4-day cells; whereas, 70 per cent of the 61 sera in which the titer with the fresh or 1-day cells was greater than 320 had lower titers with the old cells.

glutinins occurred when cells of the same age but obtained from different donors were used in tests of the same sera. Two series of experiments were carried out for this purpose; the cells of two donors were used in the first and those of 8 donors were tested in the second.

In the first experiment, blood was obtained at the same time from two donors ( $F$ and $S$ ). The bloods were washed 3 times and 2 per cent suspensions were made and stored at $5^{\circ} \mathrm{C}$. The procedure was repeated 4 days later. Sera previously found to have low or moderate titers were tested at the same time with these 4 cell suspensions. In the second experiment, erythrocyte suspensions from 8 donors were all used in tests of the same sera on the day the cells were obtained and on 5 or 6 successive days thereafter. As in the previous tests, a single series of dilutions was made of each serum and distributed into separate rows of tubes in order to minimize variations resulting from this source. In order to indicate the intensity of the reaction, both the ++ and the + end-points are recorded.
The first of these experiments was done with 27 sera. Considerable variations in the sharpness of the end-point were obtained in different sera as indicated by the discrepancies between the ++ and the + end-points. This was true for both the fresh and 4-day-old cells of each donor. A comparison of the titers obtained with the cells of the 2 donors indicated that the cells of $S$ were, in general, more sensitive to agglutination in the cold and thus gave higher titers than did the cells of $F$. The differences, however, were greater with the fresh cells, and with them the ++ endpoints obtained with the cells from both donors varied somewhat less than did the + end-points.

Thus, the fresh cells of donor $S$ showed ++ agglutinations in dilutions of 10 to 40 in 5 sera in which there was no agglutination with the cells of $F$ in the lowest dilution tested, namely $1: 10$. In the remaining 22 sera, the ++ end-point with fresh $F$ and $S$ cells was the same in 18 sera and only twice as high with the cells of the one 
or the other donor in the 4 remaining sera. The + endpoints on the other hand were higher more often with the cells of donor $\mathrm{S}$. The same + end-point was obtained with the cells of the 2 donors in only 8 sera, including 1 in which the titer was less than 10 . In all but 1 of the 19 remaining sera, the titers with $\mathrm{S}$ cells were 2 - or 4 -fold greater than with $F$ cells and in 3 of them, titers of 20 or 40 were obtained with $\mathrm{S}$ cells and no agglutination was obtained with F cells. When 4-day-old cells were used, on the other hand, there was much less difference between the cells of the 2 donors. Thus, ++ agglutination was obtained in the same titer with both $F$ and $S$ cells in 12 sera and higher titers were obtained in 9 sera with the former and 6 with the latter. The final titers $(+)$ were the same with the 2 donors' cells in 18 sera, and the remaining 9 showed only 2 -fold differences in titer, favoring the $F$ cells in 5 instances and the $S$ cells in 4.

The cells of both donors behaved alike with respect to the effect of the age of the cells. Both gave higher titers with the 4-day cells than with the fresh cells. The intensity of the cold agglutination with both donors' cells, as indicated by the ++ end-points, was correspondingly greater with the 4-day-old cells. In this respect, however, greater differences were noted with the cells of $F$ than with the cells of $\mathrm{S}$.
In summary, therefore, the cells of both $\mathrm{F}$ and $\mathrm{S}$ gave higher titers with 4-day-old cells than with fresh cells. These differences were more marked with the cells of $F$. With fresh cells, higher titers were obtained more often with the cells of S. With the 4-day-old cells on the other hand, there was essentially no difference in the results obtained with cells of the 2 donors.

In the second experiment, 6 sera of high titer from cases of atypical pneumonia were employed on 2 occasions. Here again the greatest differences were noted with the fresh cells. In general, the titers increased through the second or third day and then declined. The greatest decline, however, occurred when 5- or 6-day-old cells were used, the titers with these cells being comparable to those obtained with fresh cells. In only 1 of the 6 sera were the titers obtained with fresh cells the same or higher than with older cells. In that serum, the titers began to decline after the second day. The variations in the titers obtained with the cells of different donors were less striking than those obtained with the cells of different age ob-

TABLE II

Comparison of cold agglutinin titers obtained with Group $O$ erythrocytes of different ages and from various donors

\begin{tabular}{|c|c|c|c|c|c|c|c|c|c|c|c|c|c|}
\hline \multirow{2}{*}{ Serum } & \multirow{2}{*}{$\begin{array}{l}\text { Donor } \\
\text { of cells }\end{array}$} & \multicolumn{2}{|c|}{ Fresh } & \multicolumn{2}{|c|}{1 Day } & \multicolumn{2}{|c|}{2 Days } & \multicolumn{2}{|c|}{3 Days } & \multicolumn{2}{|c|}{4 Days } & \multicolumn{2}{|c|}{5 and 6 Days } \\
\hline & & $2+$ & $1+$ & $2+$ & $1+$ & $2+$ & $1+$ & $2+$ & $1+$ & $2+$ & $1+$ & $2+$ & $1+$ \\
\hline 1 & $\begin{array}{l}\text { A } \\
\text { B } \\
\mathbf{C} \\
\text { D } \\
\mathbf{E} \\
\mathbf{F} \\
\mathbf{G} \\
\mathbf{H}\end{array}$ & $\begin{array}{l}20 \\
20 \\
20 \\
20 \\
20 \\
20 \\
20 \\
20\end{array}$ & $\begin{array}{l}80 \\
40 \\
20 \\
80 \\
40 \\
80 \\
20 \\
40\end{array}$ & $\begin{array}{r}80 \\
80 \\
80 \\
160 \\
160 \\
160 \\
160 \\
80\end{array}$ & $\begin{array}{l}160 \\
320 \\
160 \\
320 \\
320 \\
640 \\
320 \\
320\end{array}$ & $\begin{array}{r}80 \\
160 \\
80 \\
160 \\
320 \\
160 \\
320 \\
320\end{array}$ & $\begin{array}{r}80 \\
1280 \\
640 \\
1280 \\
1280 \\
320 \\
640 \\
1280\end{array}$ & $\begin{array}{l}320 \\
320 \\
320 \\
320 \\
640 \\
160 \\
320 \\
160\end{array}$ & $\begin{array}{r}640 \\
1280 \\
320 \\
1280 \\
1280 \\
2560 \\
2560 \\
640\end{array}$ & $\begin{array}{r}160 \\
80 \\
160 \\
160 \\
80 \\
80 \\
80 \\
80\end{array}$ & $\begin{array}{l}320 \\
320 \\
640 \\
320 \\
320 \\
320 \\
320 \\
320\end{array}$ & $\begin{array}{l}80 \\
80 \\
80 \\
80 \\
80 \\
20 \\
40 \\
80\end{array}$ & $\begin{array}{r}320 \\
320 \\
80 \\
160 \\
320 \\
40 \\
80 \\
160\end{array}$ \\
\hline 2 & $\begin{array}{l}\mathbf{E} \\
\mathbf{G} \\
\mathbf{H} \\
\mathbf{I} \\
\mathbf{J} \\
\mathbf{K} \\
\mathbf{L} \\
\mathbf{M}\end{array}$ & $\begin{array}{l}320 \\
640 \\
160 \\
320 \\
160 \\
160 \\
320 \\
320\end{array}$ & $\begin{array}{r}640 \\
1280 \\
640 \\
640 \\
640 \\
640 \\
640 \\
640\end{array}$ & $\begin{array}{l}160 \\
160 \\
160 \\
160 \\
160 \\
160 \\
160 \\
320\end{array}$ & $\begin{array}{l}160 \\
320 \\
320 \\
640 \\
320 \\
640 \\
320 \\
320\end{array}$ & $\begin{array}{l}320 \\
320 \\
320 \\
160 \\
320 \\
160 \\
320 \\
320\end{array}$ & $\begin{array}{r}320 \\
640 \\
640 \\
1280 \\
640 \\
320 \\
320 \\
2560\end{array}$ & $\begin{array}{r}160 \\
160 \\
160 \\
160 \\
160 \\
80 \\
160 \\
320\end{array}$ & $\begin{array}{l}160 \\
320 \\
320 \\
160 \\
160 \\
160 \\
160 \\
640\end{array}$ & $\begin{array}{r}160 \\
80 \\
320 \\
80 \\
80 \\
160 \\
160 \\
320\end{array}$ & $\begin{array}{l}160 \\
320 \\
320 \\
160 \\
320 \\
320 \\
320 \\
640\end{array}$ & $\begin{array}{l}40 \\
80 \\
40 \\
80 \\
40 \\
80 \\
80 \\
80\end{array}$ & $\begin{array}{r}40 \\
80 \\
80 \\
80 \\
40 \\
80 \\
160 \\
160\end{array}$ \\
\hline 3 & $\begin{array}{l}\mathbf{E} \\
\mathbf{G} \\
\mathbf{H} \\
\mathbf{I} \\
\mathbf{J} \\
\mathbf{K} \\
\mathbf{L} \\
\mathbf{M}\end{array}$ & $\begin{array}{l}40 \\
40 \\
40 \\
40 \\
40 \\
40 \\
40 \\
40\end{array}$ & $\begin{array}{l}40 \\
40 \\
40 \\
40 \\
40 \\
40 \\
40 \\
40\end{array}$ & $\begin{array}{l}320 \\
320 \\
320 \\
160 \\
320 \\
320 \\
640 \\
640\end{array}$ & $\begin{array}{r}640 \\
640 \\
1280 \\
1280 \\
640 \\
640 \\
640 \\
1280\end{array}$ & $\begin{array}{l}160 \\
640 \\
320 \\
160 \\
320 \\
320 \\
320 \\
320\end{array}$ & $\begin{array}{r}320 \\
2560 \\
320 \\
640 \\
320 \\
320 \\
320 \\
1280\end{array}$ & $\begin{array}{l}320 \\
320 \\
320 \\
320 \\
320 \\
160 \\
160 \\
320\end{array}$ & $\begin{array}{l}640 \\
320 \\
320 \\
640 \\
640 \\
320 \\
320 \\
640\end{array}$ & $\begin{array}{l}160 \\
160 \\
160 \\
160 \\
160 \\
160 \\
160 \\
320\end{array}$ & $\begin{array}{l}640 \\
320 \\
640 \\
640 \\
320 \\
160 \\
320 \\
320\end{array}$ & $\begin{array}{l}80 \\
40 \\
80 \\
40 \\
80 \\
80 \\
80 \\
40\end{array}$ & $\begin{array}{r}160 \\
80 \\
80 \\
80 \\
80 \\
160 \\
160 \\
80\end{array}$ \\
\hline
\end{tabular}

* Serum 1 was tested with 5-day-old cells and sera 2 and 3 with 6-day-old cells. They were 1 to 10 weeks old at the time of these tests.

When no agglutination occurred beyond the ++ end-point, the same titer is listed under + . 
tained from the same donor. The results in 3 of the sera, which illustrate most of the variations observed, are shown in Table II.

Thus, it would appear from the results of these two experiments that the age of the cells is an important factor in the cold agglutinin titer. This is true both in sera of low and of high titer but the most marked differences are noted in sera having low titers. Considerable variations in titer are obtained with cells of the same age obtained from different donors, particularly when the sera are of low or moderate titer.

\section{COMPARISON OF TITERS WITH 2 PER CENT AND WITH 0.2 PER CENT CELLS}

In the routine test for cold agglutinins, equal volumes of 2 per cent cells were added to the serum dilutions. This concentration of cells gives a fairly heavy suspension. In sera of high or moderate titers, the readings are easily made because of the large clumps which are formed. It was considered possible, however, that agglutination of lesser intensity might be obscured because of the density of this suspension. To examine this possibility, tests were carried out simultaneously with 0.2 per cent suspensions of cells.

In these tests, the 0.2 per cent suspension was made by further dilution of the 2 per cent cells used in the same tests, 3-day-old cells from several donors being used. Batches of sera were tested simultaneously with both concentrations of cells. As before, a single series of dilutions of the serum was prepared and divided between 2 rows of tubes. A scale of reading was adapted for the tests with 0.2 per cent cells which corresponded to that used with 2 per cent cells.

The results of 400 simultaneous tests with these 2 concentrations of cells are shown in Table III. Among the 172 positive tests, slightly more than one-third yielded similar titers with both concentrations of cells. In the remaining tests, higher titers were obtained 3 times as often with 0.2 per cent cells as with 2 per cent suspensions. The

TABLE III

Cold isohemagglutinins. Comparison of titers $(1+)$ obtained with 2 per cent and with 0.2 per cent suspensions of the same cells tested simultaneously in the same sera

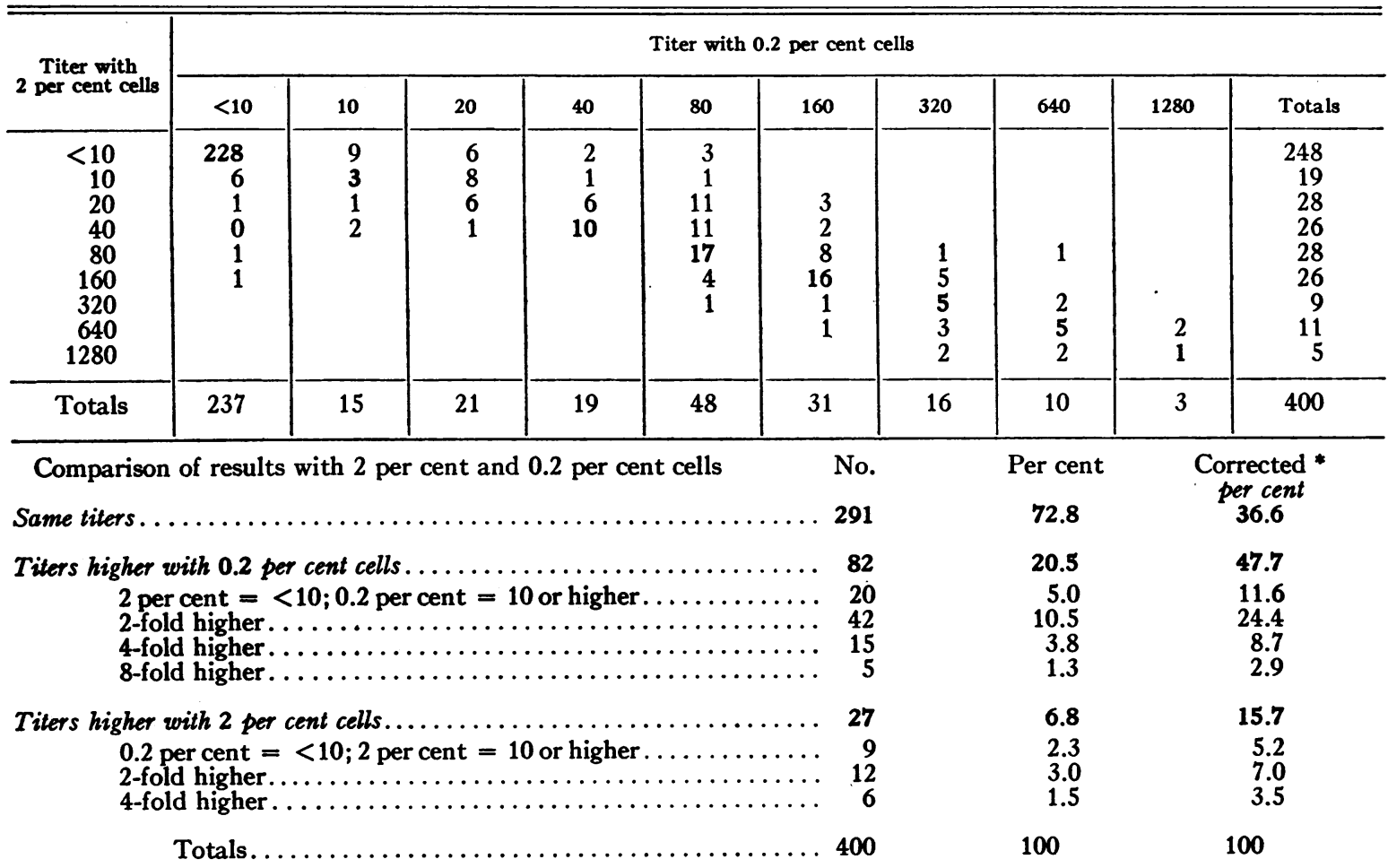

* By exclusion of the 228 tests in which the titer was $<10$ with both 2 per cent and 0.2 per cent cells. The final concentration of cells in the mixtures were $\frac{1}{2}$ of the stated amounts whereas the titers are given as the final dilution of the serum after the cells are added. 
differences, however, were not very great and occurred mostly in sera of low titer. ${ }^{1}$

\section{RESULTS WITH POOLED ERYTHROCYTES FROM SEVERAL DONORS}

One intensive experiment was carried out with 67 sera and a pool of erythrocytes derived from 8 group $\mathrm{O}$ donors. The sera varied widely in their cold agglutinin titers and were several months old at the time. One-half of the pooled blood was stored in the original citrated plasma and the cells of the remainder were washed and made up as a 2 per cent suspension in saline. The sera were tested simultaneously with 4 concentrations of fresh cells, namely $2.0,1.0,0.5$, and 0.2 per cent. On 6 successive days thereafter, the sera were retested with similar concentrations of cells in duplicate, one set of suspensions being freshly made up each day from the original stored citrated blood and the other from the cells which had been stored as a 2 per 'cent suspension in saline.

The results corroborated those of the previous experiments with respect to the age of the cells. The strongest agglutination and the highest titers were obtained with cells 2 to 4 days old, the optimum varying in different sera. With fresher and with older cells, the agglutinations were progressively weaker and the titers were lower. The concentration of the cells had much less effect. The end-points were easiest to read when the 1.0 per cent suspension was used than with the higher or lower concentrations. The titers, however, varied less than in the previous experiment in which 2.0 and 0.2 per cent suspensions were compared. The cells which were stored in the original plasma gave higher titers and clearer end-points than the cells which were stored as a 2 per cent suspension in saline.

\section{SHARPNESS OF THE END-POINT}

The simplest quantitative measure of the intensity of the cold agglutination reaction was the titer to which strong agglutination was noted. The difference between the highest concentration of serum giving strong agglutination and that at which the weakest definite agglutination is discerned can be taken as a measure of the sharpness

\footnotetext{
1 Similar observations were reported at the recent meeting of the Society of American Bacteriologists (3).
}

TABLE IV

Cold isohemagglutinin titers. Comparison of ++ and + end-points

\begin{tabular}{|c|c|c|c|c|c|}
\hline \multirow{2}{*}{ Titer ++} & \multirow{2}{*}{ Titer +} & \multicolumn{2}{|c|}{$\begin{array}{l}2.0 \text { per cent } \\
\text { cells }\end{array}$} & \multicolumn{2}{|c|}{$\begin{array}{l}0.2 \text { per cent } \\
\text { cells }\end{array}$} \\
\hline & & Sera & Percent & Sera & Percent \\
\hline \multirow[t]{2}{*}{$<10$} & $\begin{array}{r}10 \\
20 \\
40 \\
80 \\
160 \\
320\end{array}$ & $\begin{array}{r}55 \\
74 \\
60 \\
23 \\
5 \\
2\end{array}$ & $\begin{array}{l}4.1 \\
5.5 \\
4.5 \\
1.7 \\
0.4 \\
0.1\end{array}$ & $\begin{array}{r}11 \\
16 \\
7 \\
6 \\
1 \\
1\end{array}$ & $\begin{array}{r}6.9 \\
10.0 \\
4.4 \\
3.8 \\
0.6 \\
0.6\end{array}$ \\
\hline & Total & 219 & 16.3 & 42 & 26.3 \\
\hline \multirow[t]{2}{*}{10 or more } & $\begin{array}{c}\text { Same as }++ \\
2 \text {-fold } \\
4 \text {-fold } \\
\text { 8-fold } \\
\text { 16-fold }\end{array}$ & $\begin{array}{r}169 \\
615 \\
280 \\
55 \\
6\end{array}$ & $\begin{array}{r}12.6 \\
45.8 \\
20.8 \\
4.1 \\
0.4\end{array}$ & $\begin{array}{r}37 \\
56 \\
18 \\
7 \\
0\end{array}$ & $\begin{array}{c}23.1 \\
35.0 \\
11.3 \\
4.4 \\
0\end{array}$ \\
\hline & Total & 1125 & 83.7 & 118 & 73.8 \\
\hline \multicolumn{2}{|c|}{ Total positive sera } & 1344 & 100.0 & 160 & 100.0 \\
\hline
\end{tabular}

The tests with 2 per cent cells include those in which the erythrocytes were of different ages up to 4 days but the 0.2 per cent cells used in these tests were 3 days old.

of the end-point. Since there were many sera of comparatively low titer, the ++ end-point was chosen to indicate the strong reaction. The + end-point was used for the final titers since it seemed more likely, thereby, to exclude nonspecific reactions which were seen as slight agglutination $( \pm)$, visible only with magnification.

The differences between the ++ and + endpoints are summarized in Table IV. Among the sera which failed to show ++ agglutination, the + end-points ranged up to 320 . This represents differences ranging up to 64 -fold, provided that ++ agglutination were present at all in dilution below 10. In most of these sera, however, the + end-point was between 10 and 80 . The sera which showed stronger cold agglutination as indicated by ++ agglutination in titers of 10 or higher gave appreciably sharper end-points. Only rarely was there a 16 -fold difference between the ++ and + end-point, and in all but a few sera, there was a 4-fold difference or less. No definite or uniform relation was discernible between the sharpness of the end-point and the age and concentration of the cells.

From these observations it may be said that sharp end-points were associated with high titers and with strong agglutination, but in general, the 
end-points were fairly distinct considering the character of the reaction.

\section{DISCUSSION}

The test for cold agglutinins in human serum as usually performed, and as carried out routinely in the studies that were reported in this series of papers, is a very simple one to perform. In sera of high titer, it is very easy to read and to interpret. In sera of low titer, however, both the reading and the interpretation may not be so simple. Many factors may influence the quantitative results of these tests. In some sera, particularly those of low titer, the cold agglutinins may not be revealed by the test under certain circumstances. If the test for cold agglutinins is to be used as a diagnostic aid,-and its value in this respect was indicated by the data presented in the earlier papers of this series,-an acquaintance with the pitfalls and possible errors involved in the test is essential. It is for that reason that the present studies were undertaken.

Only a few of the technical features of the method as they affect the results of the test were analyzed in this paper. Others were considered in the preceding paper of this series, and the effect of storage of the sera on the titers of coldagglutinins will be considered in the paper which follows. These studies were not intended to include all of the technical details or to indicate accurately the statistical errors involved in each phase of the technique. Only some of the more important features which should be kept in mind in determining cold isohemagglutinin titers in human sera were considered.

The data presented indicate that the age of the cells that are used in the test for cold agglutinins is an important factor in determining the intensity of the cold agglutination as well as the titer, particularly in sera of low or moderate cold agglutinin content. In such sera, the use of fresh or even 1-day-old cells may fail to reveal cold agglutinins which can be demonstrated in moderate titers when 2- to 4-day-old cells are used. Furthermore, the differences in the sensitivity of cells from different donors is appreciably lessened when the older cells are used.

Cells of lower concentration than the one routinely used may also yield higher titers in some sera in which the cold agglutinin content is low. This may be due to the fact that the greater dispersion of the cells offers a better opportunity to observe minor degrees of agglutination. However, with concentrations as low as 0.2 per cent, the reading of the test is more difficult, particularly near the end-points, and 1.0 per cent suspensions are more satisfactory in this respect.

The sharpness of the end-point is, in a way, a measure of the accuracy of the quantitative measurements. In this respect, there did not seem to be any uniform differences related to the age of the cells or to their source. Here, again, the cold agglutinin content was more important, sharper end-points being obtained in sera of high titer.

From the point of view of the patient and his disease, these factors may not be of great significance. If the cold agglutinating property of serum during the course of an infection or early in convalescence is an important factor in bringing about such complications as hemolytic anemia, thrombophlebitis, acrocyanosis, etc., it is obviously only the patient's own circulating cells and plasma which are involved. The conditions to which the blood is subjected in various parts of the body and its content of cold autohemagglutinins are probably the only factors which are of importance. Of these, only a measure of the autohemagglutinin content is obtainable in the test tube; its relation to isohemagglutinins was considered in the preceding paper.

\section{SUMMARY AND CONCLUSIONS}

The results of comparative tests for cold isohemagglutinins carried out simultaneously with cells of different age, from different donors, and in different concentrations were presented. Considerable variations in the intensity of the agglutination and in the titers were obtained in individual sera under these conditions. The greatest variations were obtained in sera in which the cold agglutinin content was low. In such sera, the use of cells which were 2 to 4 days old gave significantly higher titers with greater regularity than did fresh or 1-day-old cells. With the 2- to 4-dayold cells, moreover, the differences between the titers obtained with the use of cells from different donors were minimized. Cells more than 4 days 
old behaved in these respects more like fresh cells. In comparative tests, in which 2 per cent and 0.2 per cent cells were used, the latter yielded higher titers more frequently than the former. A concentration of 1.0 per cent, however, proved more satisfactory technically. Cells stored in the original plasma were more satisfactory than those which were stored in saline.

\section{BIBLIOGRAPHY}

1. Finland, M., Peterson, O. L., Allen, H. E., and Samper, B. A., Cold agglutinins. I. Occurrence of cold isohemagglutinins in various conditions. J. Clin. Invest., 1945, 24, 451.

2. Ham, T. H., Personal communication.

3. Commission on Acute Respiratory Disease, Cold hemagglutinins in primary atypical pneumonia and other respiratory infections. Am. J. M. Sc., 1944, 208, 742. 